UDC 141.7: [81'27+33]

Z. S. Vykhovanets, Candidate of Philosophy Sciences

\title{
GRAMMAR OF MODERN ECONOMICS: FUNDAMENTAL TYPES
}

Abstract. The article is devoted to the analysis of socio-economic relations through the prism of study of the linguistic cognitive structures and grammar for the purpose of objectification of the indicated scope of reality, determines certain rules of use of linguistic practices that ensure the formation, transmission, acquisition of knowledge in the process of communicative interaction. The economic content of the value phenomenon allows to figure out the process of how goods enter the exchange system and how they compare with each other on the principles of equivalence and similarity that eventually allows to evaluate them. Accordingly, the value corresponds to the attributive function of a verb in grammar, when the sentence statement forms the starting point of the language. The continuous process of exchange is provided by the constant breakdown of the value of a particular object by all other estimating values, and it is here that the value begins to perform the function of the joint which the general grammar recognizes for all nonverbal components of a sentence that perform the function of naming. This game of values allows every part of the wealth to be both defined and defining component at the same time, as well as value becomes both the verb and the noun at the same time, i.e. the theory of trade and money relations demonstrates how any object can acquire a function of a definitive in the correlation with another object and become its constant sign.

Claiming that language is a material bearer of social-communicative interaction between people, it is determined that the fundamental grammar typology and fundamental typology of socio-economic relations are identical to each other, and the mechanism of formation of the categorical apparatus of the modern language in the field of economic knowledge takes characteristics of a peculiar procedure of objectification of individual human consciousness and ensures formation of a mosaic cultural tradition in the process of transformation of the world economy.

Keywords: human; economy; linguistic cognitive structures; grammatical method; values; capital; cost; labor.

3. С. Вихованець, к. фрілос. н.

\section{ГРАМАТИКА СУЧАСНОЇ ЕКОНОМІКИ: ФУНДАМЕНТАЛЬНА ТИПОЛОГІЯ}

Анотація. У статті здійснюється аналіз соціально-економічних відносин через призму дослідження мовленнєвих пізнавальних структур і граматики з метою об'єктивізації зазначеної сфрери реальності. Стверджуючи про те, що мова $є$ матеріальним носієм соиіальнокомунікативної взаємодії між людьми, визначається, що фунндаментальна типологія граматики та фундаментальна типологія суспільно-економічних відносин є тотожними між собою, а механізм становлення категоріального апарату сучасної мови у сфрері економічних знань набуває ознак своєрідної процедури об'єктивізації індивідуальної свідомості людини та забезпечує фрормування мозаїчної культурної традиції в процесі трансформації світового господарства.

Ключові слова: людина; економіка; мовленнєві пізнавальні структури; граматичний метод; цінності; капітал; вартість; праця.

3. С. Выхованец, к. филос. н.

\section{ГРАММАТИКА СОВРЕМЕННОЙ ЭКОНОМИКИ: ФУНДАМЕНТАЛЬНАЯ ТИПОЛОГИЯ}

Аннотация. В статье осуществляется анализ социально-экономических отношений через призму исследования языковых познавательных структур и грамматики с целью объективизации указанной сфреры реальности. Утверждая про то, что язык является материальным носителем социально-коммуникативного взаимодействия между людьми, определяется, что фрундаментальная типология грамматики и фундаментальная типология общественно-экономических отношений являются тождественными между собой, а механизм станов- 
ления категориального аппарата современного языка в сфрере экономических знаний приобретают черты своеобразной процедуры объективизации индивидуального сознания человека и обеспечивают фрормирование мозаччески культурной традиции в процессе трансформации мирового хозяйства.

Ключевые слова: человек; экономика; языковые познавательные структуры; грамматический метод; ценности; капитал; стоимость; труд.

Relevance of the object of the study. The current structure of the economy of post-industrial era has several ways of manufacture, and the classical approach to industrial capital which was focused on the use of the maximum volumes of objectificated permanent capital is now including the characteristics of intangible capital. The above changes of socio-economic system of the globalized world significantly affect the substantial filling of such key categories as the value, money, capital, man power, labour, etc. Open topics for discussion by the scientific environment still include the analysis of the socio-economic field of knowledge through the prism of study of the language cognitive structures and grammar for the purpose of learning the indicated scope of reality, certain rules of use of linguistic practices that ensure the formation, transmission, acquisition of knowledge in the process of communicative interaction are determined: "Grammatical method insists that the negative sides of public life encourage us to think, speak, write, learn, and nothing can get us to think realistically. Our analysis of social turmoil and danger leaves aside all individual troubles of s single and lonely human being" [2, p. 14].

Therefore, the study of the mechanism of formation of the categorical apparatus of the modern language in the field of socio-economic knowledge as a peculiar procedure of objectification of individual human consciousness and formation of a mosaic cultural tradition in the process of transformation of the world economy is undoubtedly an urgent task.

Problem statement. The point is that the exchange value of tangible and intangible products ultimately depends on their content of information knowledge and human intellect instead of the amount of the aggregate social labour put in them. Therefore, such a kind of cognitive labour activity creates the size and the ratio of the goods value clearly uncertain and difficult to predict because the "communicative" component of the manufacture outcome is ignored.

Analysis of recent studies and publications. Discussion about the semantic content of the categories of the economic knowledge apparatus goes through the entire history of the economic theoretical idea. Plato and Aristotle claimed the discrete nature of categories due to the fact that the world is divided on non-crossing classes of subjects, whereas categories have established boundaries. Subsequently, an alternative position was formed by L. Wittgenstein, who claimed that all categories are relative and have diffusive character. Accordingly, a network of these bonds is formed which have a center and periphery. And periphery contributes to adding new meanings to the content of categories, and mutual penetration of peripheral areas of several categories also becomes a significant factor in the transformation of a single semantic field.

Representatives of structuralism use language and some of its methods as the basis of the scientific approach of research in the field of the humanities, for example, methods of linguistics in the theoretical ethnography of religious structures of primitive tribes are used by C. Lévi-Strauss; the proposed methodology for the analysis of the present is used by R. Bart, and the linguistic analogy is translated to a human psyche by J. Lacan, etc. In his turn, M. Foucault proposes a new way to the relationship between words and things in the system of wealth analysis as such that is an invaluable contribution to understanding the modern changes in the socio-economic character in the face of globalization. It is signification of the classical period of research in language that correlates with the mechanism of the value in the material production, the analysis of which was proposed by K. Marx. Similar to the ideas of K. Marx, Wittgenstein also defines the public life as a form of practice, and not just as a set of people's attitudes and beliefs, and such representatives as Condillac, Galiani, Gralen proceeded from the exchange of profitability as from subjective base of all values.

A kind of comparative analysis between the exchange of linguistic elements and functioning of the money was first provided in the literature by F. de Saussure. The main properties of the money are the possibility to be exchanged for real material benefits and the possibility for a currency unit to be correlated with other units of the monetary system, i.e. the fact of correlation of all elements of the internal system. Accordingly, the possibility of a currency unit to be exchanged for real material benefits is a 
process similar to the structural dimension of a language, and the process of internal correlation of the monetary system elements is similar to the functional distribution in the language. These approaches correspond to the period of the classical explanation of the linguistic sign which is subordinate to the market law of value and directs the language structural operations towards designata. It is significata of the classical period of research in language that correlate with the mechanism of the value in the material production, the analysis of which was proposed by K. Marx.

Outlining previously unexplored parts of the general problem. In this case, we observe profound changes in the law of values, that is, it becomes necessary to consider the permanent destruction of social relations governed by value, determinacy of relations disappears - all this is changing the general approach to the understanding of the nature of existence of the economy itself. Claiming that language is a material bearer of social-communicative interaction between people, we determine that the fundamental grammar typology and fundamental typology of socio-economic relations are identical to each other, and the mechanism of formation of the categorical apparatus of the modern language in the field of economic knowledge takes characteristics of a peculiar procedure of objectification of individual human consciousness and ensures formation of a mosaic cultural tradition in the process of transformation of the world economy.

Task statement. There is no such a problem statement in the scientific literature; therefore, the purpose of this publication is to study the fundamental grammar and modern economy typology.

Summary of the basic material. In the system of modern cognitive capitalism, knowledge becomes a factor of production, as much necessary as labor or capital; in fact, knowledge accumulates the cost of labor and other production factors that are necessary for its manufacture. Using the knowledge, the manufacturing process itself is further managed, thus creating a useful product for the consumer. In the manufacturing process of industrial capitalism, labour generates knowledge, and knowledge further generates the value. In order to increase, the capital should use not only labour, but also the knowledge that it generates and includes in the production cycle. But in terms of modern cognitive capitalism, the use of knowledge cannot simply be restricted by the capital, as the conversion of knowledge into value is governed by specific laws that are missing in the Marxist and liberal theories of value.

Conversion of knowledge into value, especially when it is taken in a virtual form, creates many ambiguous components in the value circulation. The above process of converting knowledge into value has a nonlinear, unstable, often disastrous and time-impermanent nature, but this form of existence itself creates a space of freedom for new and original institutional transformations. In addition, it is very important that knowledge, as any product, have a user value to society but they do not have the cost base which could be used as a reference for determining the exchange value. It is necessary to add that knowledge is functioning from the perspective of Marxist theory as the reproduction costs, and neoclassical theory recognizes them as marginal costs. Indeed, the cost of knowledge production is very uncertain and it significantly differs from the cost of its reproduction, for example, when the first sample of the intellectual activity is created, all further developments are losing their meaning.

Therefore, the exchange value of knowledge depends on the practical possibility to limit its free circulation due to the improvement of copyright protection. The cost of knowledge is not a product of natural rarity, it is only created due to institutional constraints of access to knowledge.

F. de Saussure provides a comparative analysis between the exchange of linguistic elements and functioning of money [3]. The main properties of the money are the possibility to be exchanged for real material benefits and the possibility for a currency unit to be correlated with other units of the monetary system, i.e. the fact of correlation of all elements of the internal system. Accordingly, the possibility of a currency unit to be exchanged for real material benefits is a process similar to the structural dimension of a language, and the process of internal correlation of the monetary system elements is similar to the functional distribution in the language. These approaches correspond to the period of the classical explanation of the linguistic sign which is subordinate to the market law of value and directs the language structural operations towards designata. It is signification of the classical period of research in language that correlates with the mechanism of the value in the material production, the analysis of which was proposed by K. Marx.

In his turn, J. Baudrillard describes the specified process as follows: "use value plays the role of a horizon in the target figure in the exchange value system - the first characterizes the specific operation carried out with the goods in the course of consumption (the point similar to the sign designation), the 
second sends to the ability of all goods to be exchanged between themselves according to the law of equivalence (the point similar to the structural organization of the sign), and they are both dialectically correlated throughout the whole analysis by Marx defining the rational arrangement of production that is governed by the political economy" [1, p. 51], - however, the new radical revolution ended the classic perception of economic laws.

The classic combination of the two aspects of the value breaks down due to the fact that the referential value has been destroyed, i.e. the equivalence to the real contents of objects disappears and the structural game of values is gradually formed, a phenomenon of simulation emerges. It lies in the fact that all the signs begin to exchange between themselves but no longer exchange with anything real, that is, the rules of determined equivalence in a language no longer work, neither do the target figures of production, and the monetary unit does not correspond to the real production, it is exposed to constant/uncontrolled inflation and speculation.

Therefore, we can state a modern process of disintegration of the dialectics of interaction between the reality and the sign; according to J. Baudrillard, ex-termination of the production and the sign reality takes place, which provides the appearance of political economy of the sign.

In this case, we observe profound changes in the law of values, that is, it becomes necessary to consider the permanent destruction of social relations governed by value, determinacy of relations disappears - all this is changing the general approach to the understanding of the nature of existence of the economy itself. In its turn, the notion of the sign changes its meaning in the same way, the sign ceases to be a form of structural law of values, it is represented by such a specific organization as code. The matter is that the market law of value does not mean the determining role of material production, as well as structural law of values does not determine the priority of a specific sign. The market law of value was developed by Marx on the basis of research of the material production of goods, whereas the structural law of values was developed by Saussure based on the linguistic sign. However, the market law of value is actually the law of equivalence that fully regulates the configuration of the sign when the equivalence of the signifier and the signified provides a regular exchange of referential contents. As we can see, the classic law of value simultaneously functions both in the system of production and in the field of language and, on the contrary, the structural law of values provides both non-determinacy of these fields against one another, and, accordingly, the content of each component, i.e. the transition from the determined field of signs to non-determined field of code occurs.

Therefore, the test of the market law of value on the sign material confirms both the process of exchange of contents and simultaneous loss of its balance, and also the fact that with the emergence of code they are moving into the state of simulation. It is the capital that cancels the determinacy of the society by way of production and replaces it with the structural form of value: "era of simulation opens the possibility of mutual substitution of elements that previously had the character of a contradiction or were dialectical opposites... In our system of images and signs, all the basic humanistic criteria of values that defined the centuries-old culture of moral, aesthetic, practical judgments disappear. All things cannot be solved - the characteristic effect of a rule of the code fully based on the principle of neutralization and impossibility to distinguish. It is, so to speak, a global mess of capital - not for prostitution, but for substitution and commutation" [1, p. 55].

In its turn, the immediate reality of the socio-economic life is that there are things without which a person can do all his/her life, but instead (s)he credits them with high value and pays huge funds, while physiologically necessary things cost a penny, "It is no longer the question of learning the mechanism according to which wealth can be imagined among the likes (due to the universal idea of wealth which a precious metal is), but figuring out why objects of desire and need must be presented, thus the value of things is determined, and why it can be claimed that it is worth this much or that much" [4, p. 217].

Within the classical thinking, the perceptions of such concepts as value is associated with the fact that any thing should be something worth and it is "something" that is only detected in the process of exchange to an equivalent "something" in a different thing. Money and prices exist and vary because there is the process of exchange, but the external perception of this process alone does not give basic answers to the functional substance of the phenomenon of exchange. When a person comes into the process of exchange, (she) has to recognize the value of the things (s) he wants to purchase; at the same time, (s)he offers for exchange the value of her/his thing. The main thing here is the fact that the person cannot originally use her/his thing offered for exchange. Then how do all the people know the 
value of the things they exchange if they have never practically used them before the fact of exchange? The point is that value only exists inside an idea or inside the exchange itself, i.e. there is only the ability to exchange that really exists.

Therefore, there are two grammatical approaches in the analysis of economic phenomena which are possible: the value is the primary and it was laid in the things prior to the fact of exchange, and here the essence of language is presented in primary definitions, i.e. the language of actions or the language of roots is proposed; the value appears only at the moment of the process of exchange of things and this is the only way it can exist, in this case, the general functionality of the language within a sentence, and from the point of view of logic - judgment, is analyzed.

Hence, the possibilities of grammar explanation of metaphysical nature of such category as value arise. In the first case, we go beyond the limit of the linguistic analysis form and determine the essence of the exchange process in the natural similarity of things, i.e. the appearance of the word base itself was provided by the need for combined actions of individuals with respect to meeting their vital needs. In another variant, the language, by using a verb which allows all the words of language possible, provides for their ratio due to their prepositional connection, this is the same way to provide for the exchange that defines the value of exchanged things and their sale price as a primary act [4, p. 218]. Unlike the economy, when the desire to exchange the thing and the process of exchange itself are identical, that is the definition itself represents the process of establishing an activity connection, the grammar thus provides the system of views when the object value is determined and the judgment is formed at the same time enabling to establish its truth. In this way, a specific combination of linguistic and economic approach to the formation of a social phenomenon of value takes place.

Thus, using the grammar, we are offered the following possible explanations, for example, the theory of value as an analysis of the judgment and analysis of the action or the base; economics, in its turn, offers to analyze the value based on the usefulness of objects, and then determines the value based on inexhaustible possibilities of nature.

Grammar system, when analyzing words coming from the base and combining the sound and the thing itself, creates a process of abstraction formation, which provides the procedure for obtainment by the base of a name in language. Accordingly, M. Foucault proposes such a category as the game of values [4, p. 227]: exchange provides price to any things at the same time reducing the price of each thing. On the one hand, the exchange increases the value due to creation of usefulness as such satisfying human needs, on the other hand, it reduces the value in the process of evaluation of each individual thing, i.e. there is a correlation dependence due to the exchange when useless becomes useful and more useful becomes less useful.

Therefore, the phenomenon of value allows to figure out the process of how goods enter the exchange system and how they compare with each other on the principles of equivalence and similarity that eventually allows to evaluate them. As we see, the value corresponds to the attributive function of a verb in general grammar, when the sentence statement forms the starting point of the language. The continuous process of exchange is provided by the constant breakdown of the value of a particular object by all other estimating values, and it is here that the value begins to perform the function of the joint which the general grammar recognizes for all nonverbal components of a sentence that perform the function of naming.

In its turn, this game of values allows every part of the wealth to be both defined and defining component at the same time, as well as value becomes both a verb and a noun at the same time, i.e. the theory of trade and money relations demonstrates how any object can acquire a function of a definitive in the correlation with another object and become its constant sign. In addition, this situation allows to analyze the process when never disappearing monetary element could mean the increase or decrease in wealth, how it may vary in relation to the value it represents.

Conclusions. We can claim that the theory of monetary price corresponds to the similar process in the grammar of the language in the form of analysis of the roots and language of action and performs the function of diversion or displacement of meaning. Money, like words, should perform the function of definition: price balancing represents a process of balancing between the monetary metal and all types of wealth and is similar to the process of rhetorical offset to the original meaning of verbal signs. Intelligence becomes an attribute of living labor, which in turn increasingly takes the form of linguistic actions. Modern cognitive capitalism of the 21 st century determines the form of existence of living labour as linguistic-communicative, whereas modern economic projects with their clear time, financial 
and strategic-space certainty are doomed to enforce the mobile and communicative nature of work. Language becomes a necessary attribute of the social nature of labour productivity, and the nature of language as a social good is more specific than identifying it in a system of various knowledge. According to K. Marx, language is a natural unalienated way of existence of the society, its axis of being, and in the modern telecommunication genesis, the functional significance of language becomes an attributive way of existence of such society and, as we can see, the mechanical part of the basic capital is gradually becoming less significant in comparison with various types of immaterial labour, including on the basis of computer support.

\section{References}

1. Baudryard, J. (2004). Symvolichniy obmin i smert [The symbolic exchange and death]. Lviv: Kalvaria [in Ukrainian].

2. Rosenstock-Huessy, E. (1994). Rech i deistvitelnost [Speech and reality]. Moscow: Labirint [in Russian].

3. Saussure, F. (1977). Trudi po yazikoznaniyu [Works in Linguistics]. Moscow: Progress [in Russian].

4. Foucault, M. (1977). Slova i veschi. Arkheologiya gumanitarnih nauk [Words and Things. Archeology of humanities]. Moscow: Progress [in Russian].

\section{Література}

1. Бодріяр, Ж. Символічний обмін і смерть / Жан Бодріяр. - Львів : Кальварія, 2004. - 376 с.

2. Розеншток-Хюсси, О. Речь и действительность / Ойген Розеншток-Хюсси. - М. : «Лабиринт», 1994. - 224 с.

3. Соссюр, Ф. Труды по языкознанию / Ф. Соссюр. - М. : Прогресс, 1977. - 695 с.

4. Фуко, М. Слова и вещи. Археология гуманитарных наук / М. Фуко. - М. : «Прогресс», 1977. - 407 с.

Received for publication 10.02.2017

Бібліографічний опис для цитування :

Вихованець, 3. С. Граматика сучасної економіки: фундаментальна типологія / 3. С. Вихованець // Проблеми соціальної роботи: філософрія, психологія, соціологія. - 2017. - № 1 (9) . - С. 14-19. 